\title{
Density and richness of leaf litter frogs (Amphibia: Anura) of an Atlantic Rainforest area in the Serra dos Órgãos, Rio de Janeiro State, Brazil
}

\author{
Carla C. Siqueira 1, 2; Davor Vrcibradic 1; Mauricio Almeida-Gomes 1; Vitor N. T. Borges-Junior 1; \\ Patrícia Almeida-Santos 1; Marlon Almeida-Santos 1; Cristina V. Ariani 1; Diego M. Guedes 1; \\ Pablo Goyannes-Araújo ${ }^{1 ;}$; Thiago A. Dorigo ${ }^{1}$; Monique Van Sluys ${ }^{1} \&$ Carlos F. D. Rocha ${ }^{1}$ \\ ${ }^{1}$ Departamento de Ecologia, Universidade do Estado do Rio de Janeiro. Rua São Francisco Xavier 524, Rio de Janeiro, \\ 20550-011 Rio de Janeiro, Brasil. \\ 2 Corresponding author. E-mail: carlacsiqueira@yahoo.com.br
}

\begin{abstract}
Data on species composition, richness, and density are presented for the leaf litter frog assemblage of an area of Atlantic Rainforest at the Serra dos Órgãos mountain range, in the state of Rio de Janeiro, southeastern Brazil. Three sampling methods were used: plot sampling, visual encounter surveys, and pitfall traps. The local assemblage of leaf litter frogs was composed of 16 species, with the direct-developing species, Euparkerella brasiliensis (Parker, 1926), being the most abundant. The estimated density of the local leaf litter frog assemblage based on plot sampling was 17.1 ind $/ 100 \mathrm{~m}^{2}$ and the estimated overall leaf litter frog mass was $684.2 \mathrm{~g} / \mathrm{ha}$. The estimated density of leaf litter frogs at the present study is the highest currently reported for Atlantic Rainforest areas, which reinforces the idea of higher densities of leaf litter frogs in the Neotropical Region compared to the Old World tropics.
\end{abstract}

KEY WORDS. Amphibian survey; relative abundance; tropical forest.

The leaf litter of most tropical forests is the habitat of a rich herpetofauna, mainly composed of small lizards and frogs (e.g., Heatwole \& Sexton 1966, Lloyd et al. 1968, Scott 1976, 1982, Inger 1980, Heinen 1992, Vonesh 2001, Almeida-Gomes et al. 2008). Leaf litter frogs tend to be more abundant in Neotropical forests when compared to the Old World tropics (ScotT 1976, 1982, Allmon 1991, Vonesh 2001), although this is not a rule (Hofer \& Bersier 2001, Watanabe et al. 2005). The reasons for this difference are not clear, but may be in part due to the greater availability of nutrients in many Neotropical areas, associated with their more recent geological age (ALLMON 1991).

Environmental and structural parameters at each locality partially explain the differences in species richness and density among communities (e.g. Scotт 1976, Watanabe et al. 2005, VAN SLuYs et al. 2007). Some studies about litter frogs in tropical forests have included density estimates, which allow quantitative comparisons among anuran faunas (AlLMON 1991 and included references, GiaretTa et al. 1997, 1999, RосHA et al. 2001, 2007, Huang \& Hou 2004, Watanabe et al. 2005, Almeida-Gomes et al. 2008). In South America, studies of tropical forest leaf litter frog assemblages providing data on frog densities are still relatively rare, particularly with regard to the Brazilian Atlantic Rainforest (GiaretTA et al. 1997, 1999, Rосна et al. 2000, 2001, 2007, van Sluys et al. 2007, AlmeIDA-Gomes et al. 2008). The Atlantic Rainforest extends along the eastern coast of Brazil and is considered as one of the world's biodiversity hotspots because of its high biological diversity and rates of endemism, and severe deforestation rate (Myers et al. 2000). This biome may harbor the world's greatest diversity of anuran species (Duellman 1999, Young et al. 2004).

Despite intense deforestation, the state of Rio de Janeiro still has proportionately large forested areas (TANIZAKI-FonsECA \& Moulton 2000, Rocha et al. 2003) and has relatively high anuran endemism rates (RochA et al. 2004). Herein, data are presented on species composition, richness, relative abundance, and density for the leaf litter anuran assemblage of an area within the Serra dos Órgãos mountain range, which represents one of the largest continuous areas of Atlantic Rainforest in the state of Rio de Janeiro (Rocha et al. 2003). The results are compared with those reported for other studied rainforest areas worldwide.

\section{MATERIAL AND METHODS}

The Parque Estadual dos Três Picos (hereafter PETP) is a recently created conservation unit that encompasses much of the Serra dos Órgãos mountain range, and extends along five municipalities in the state of Rio de Janeiro, in southeastern Brazil. With an area of more than 46,000 ha, it comprises one of the most extensive areas of Atlantic Rainforest in the state (Rocha et al. 2003). The study was carried out within a private property (Fazenda Santa Bárbara; $22^{\circ} 25^{\prime} \mathrm{S}$ and $42^{\circ} 35^{\prime} \mathrm{W}$ ) located inside the PETP, in the municipality of Cachoeiras de Macacu. The annual rainfall in the area is approximately $2,500 \mathrm{~mm}$ and the mean annual temperature varies between 16 and $18^{\circ} \mathrm{C}$. 
Surveys were conducted during late October and early November 2006 at altitudes between 500 and 800 m, using three sampling methods: plots or quadrats (JAEGER \& INGER 1994), visual encounter surveys (CRUMP \& SCOTT 1994), and pitfall traps with drift fences (CORN 1994).

For the plot method, 25 quadrats of $5 \times 5 \mathrm{~m}$ were established on the forest floor during the afternoon, totaling 625 $\mathrm{m}^{2}$ of sampled area. The corners of each plot were marked with wooden stakes and the area inside was enclosed with a $50 \mathrm{~cm}$ high soft plastic fence, whose base was buried or attached to the ground. After sunset, each plot was carefully searched for about 30 minutes by five people using headlamps, moving on hands and knees, side-by-side. During the search, leaves, branches, and stones were overturned with hand rakes; rock crevices and fissures among tree roots were also checked.

For visual encounter surveys, 150 transects lasting $30 \mathrm{~min}$ each were carried out by 10 people, totaling 75 hours of sampling effort (7.5 h/person). Equal numbers of transects (50) were surveyed during each period of the day (diurnal, crepuscular, and nocturnal). During each transect sampling, the observer moved at a slow walking pace, carefully searching all types of potential microhabitats for frogs.

Three pitfall trap systems were used during a total of 18 days. Each system consisted of 10 30-liter buckets buried on the ground and set ca. $5 \mathrm{~m}$ apart, with soft plastic drift fences about $50 \mathrm{~cm}$ high extended among them. Six buckets were set in line and the other four were placed at opposite ends of the fence, perpendicularly to the main axis. Pitfalls were checked once a day, always in the morning.

All frogs found using the three sampling methods were collected and identified. Besides, all individuals found during casual encounters were also recorded. For an estimate of species composition and richness of the leaf litter frog assemblage, the species recorded by all three sampling methods plus those collected during casual encounters were considered. For estimates of density only the data obtained by plot sampling were considered, as this method has been frequently used in tropical forests worldwide (e.g. Allmon 1991, Watanabe et al. 2005) and allows comparisons with other forested areas for which data is available. The total mass of leaf litter frogs per hectare ( $\mathrm{g} / \mathrm{ha}$ ) was also estimated. Voucher specimens of all frog species recorded during the study were deposited at the Museu Nacional, Rio de Janeiro.

\section{RESULTS}

Sixteen frog species belonging to eight families were recorded in the leaf litter during the study (Tab. I). The local anuran assemblage was dominated by species with direct development (Terrarana sensu Hedges et al. 2008), with Euparkerella brasiliensis (Parker, 1926) being the most abundant species (comprising $51 \%$ of all individuals collected), followed by Brachycephalus didactylus (Izecksohn, 1971) (16\%). The species with the highest mean body mass were Rhinella icterica (Spix,
1824) $(91.2 \pm 88.0 \mathrm{~g})$, followed by Proceratophrys appendiculata (Günther, 1873) (36.0 g), R. ornata (Spix, 1824) (35.2 $\pm 21.8 \mathrm{~g}$ ), and $P$. boiei (Wied-Neuwied, 1824) $(32.0 \pm 14.4 \mathrm{~g})$, whereas $B$. didactylus $(0.07 \pm 0.02 \mathrm{~g})$ was the species with lowest mean body mass (Tab. I).

A total of 107 individuals belonging to seven frog species were found in the plots (Tab. I). Three frogs escaped (one E. brasiliensis, one $B$. didactylus and one individual that could not be identified). The estimated overall frog density of the local leaf litter frog assemblage was $17.1 \mathrm{ind} / 100 \mathrm{~m}^{2}$, and the estimated overall frog mass was $684.2 \mathrm{~g} / \mathrm{ha}$ (Tab. I). The frogs that occurred with the highest densities were E. brasiliensis $(9.6$ ind $/ 100 \mathrm{~m}^{2}$ ) and $B$. didactylus $\left(4.0 \mathrm{ind} / 100 \mathrm{~m}^{2}\right)$, which together comprised about $80 \%$ of all individuals found in plots. Hylodes pipilans Canedo \& Pombal, 2007 was the species with the lowest estimated density $\left(0.2\right.$ ind $\left./ 100 \mathrm{~m}^{2}\right)$ on the forest floor. The species with the highest estimated mass per hectare were $E$. brasiliensis (380.3 g/ha) and Haddadus binotatus (Spix, 1824) (150.1 g/ha), whereas $H$. pipilans $(8.1 \mathrm{~g} / \mathrm{ha})$ and Ischnocnema parva (Girard, 1853) (9.4 g/ha) had the lowest estimated mass per hectare (Tab. I).

Twelve frog species were recorded during transect samplings, with E. brasiliensis ( $\mathrm{N}=23$, or $56 \%$ of all individuals found) being the most abundant (Tab. I). Almost all frog species sampled in transects were found during the crepuscular period $(\mathrm{N}=10$ species, or $83 \%$ of the species in the assemblage), whereas only three (B. didactylus, Zachaenus parvulus (Girard, 1853), and E. brasiliensis) were found during diurnal samplings (25\%). Most individuals were found during crepuscular $(\mathrm{N}=24$, or $58 \%$ of all individuals sampled) and nocturnal $(\mathrm{N}=14$, or $34 \%)$ transects, whereas the proportion of frogs found during diurnal transects $(\mathrm{N}=3$, or $7.3 \%)$ was comparatively lower.

Twelve frogs belonging to seven species were captured by pitfall traps (Tab. I). The most frequently captured species in the pitfalls were $R$. icterica $(\mathrm{N}=4$, or $33 \%$ of all specimens captured) and E. brasiliensis ( $\mathrm{N}=3$, or $25 \%)$.

\section{DISCUSSION}

Our data indicate that frog density at the studied area is relatively high, as the estimated total density was twice as high as that of another Atlantic Forest area (Reserva Ecológica de Guapiaçu) located only ca.15 km from the study area (Tab. II). Other "large-plot" studies have yielded even lower density estimates for different Atlantic Forest areas of southeast Brazil (1.4-5.9 ind/100 $\mathrm{m}^{2}$; Tab. II). In fact, estimated density of leaf litter frogs at the Fazenda Santa Bárbara is the highest yet reported for Atlantic rainforest areas. Considering other tropical rainforest areas worldwide for which litter frog densities were estimated (Tab. II), our data for the PETP is also on the high side. The estimated leaf litter frog density in our study was higher than that of a survey conducted in the Brazilian Amazon, but close to that reported for a Peruvian site during the 
Table I. Number of individuals recorded for each sampling method and mean body mass ( \pm one standard deviation) of each species, and estimated density and mass per area of frogs recorded in the leaf litter of an Atlantic Rainforest area within the Parque Estadual dos Três Picos, in southeastern Brazil.

\begin{tabular}{|c|c|c|c|c|c|c|c|c|}
\hline Species & Plots & Transects & Pitfalls & Extra & Total & $\begin{array}{l}\text { Body mass } \\
(\mathrm{g})\end{array}$ & $\begin{array}{c}\text { Density } \\
\text { (frogs } / 100 \mathrm{~m}^{2} \text { ) }\end{array}$ & Mass (g/ha) \\
\hline \multicolumn{9}{|l|}{ Brachycephalidae } \\
\hline Brachycephalus didactylus (Izecksohn, 1971)* & 25 & 2 & & 1 & 28 & $0.07 \pm 0.02$ & 4.0 & 26.1 \\
\hline Ischnocnema guentheri (Steindachner, 1864) & 5 & 2 & & 4 & 11 & $1.00 \pm 0.50$ & 0.8 & 56.0 \\
\hline I. parva (Girard, 1853) & 3 & 2 & & & 5 & $0.30 \pm 0.10$ & 0.5 & 9.4 \\
\hline I. octavioi (Bokermann, 1965)* & & 1 & & & 1 & 0.20 & & \\
\hline \multicolumn{9}{|l|}{ Craugastoridae } \\
\hline Haddadus binotatus (Spix, 1824) & 3 & & & & 3 & $3.30 \pm 2.40$ & 0.5 & 150.1 \\
\hline \multicolumn{9}{|l|}{ Cycloramphidae } \\
\hline Proceratophrys appendiculata (Günther, 1873) & & & 1 & & 1 & 36.00 & & \\
\hline P. boiei (Wied-Neuwied, 1824) & & 3 & & 4 & 7 & $32.00 \pm 14.40$ & & \\
\hline Thoropa miliaris (Spix, 1824) & & & 1 & & 1 & 26.20 & & \\
\hline Zachaenus parvulus (Girard, 1853) & 9 & 2 & 1 & 4 & 16 & $1.10 \pm 0.80$ & 1.4 & 54.2 \\
\hline \multicolumn{9}{|l|}{ Hylodidae } \\
\hline Crossodactylus aeneus Müller, 1924 & & 2 & & & 2 & $1.10 \pm 0.40$ & & \\
\hline Hylodes pipilans Canedo \& Pombal, 2007* & 1 & 1 & & & 2 & $0.70 \pm 0.20$ & 0.2 & 8.1 \\
\hline \multicolumn{9}{|l|}{ Leptodactylidae } \\
\hline Leptodactylus marmoratus Steindachner, 1867 & & 1 & & & 1 & 1.20 & & \\
\hline \multicolumn{9}{|l|}{ Bufonidae } \\
\hline Rhinella icterica (Spix, 1824) & & 1 & 4 & & 5 & $91.20 \pm 88.00$ & & \\
\hline R. ornata (Spix, 1824) & & & 1 & 1 & 2 & $35.20 \pm 21.80$ & & \\
\hline \multicolumn{9}{|l|}{ Microhylidae } \\
\hline Myersiella microps (Duméril \& Bibron, 1841) & & 1 & 1 & & 2 & $0.70 \pm 0.20$ & & \\
\hline \multicolumn{9}{|l|}{ Strabomantidae } \\
\hline Euparkerella brasiliensis (Parker, 1926)* & 60 & 23 & 3 & 3 & 89 & $0.40 \pm 0.20$ & 9.6 & 380.3 \\
\hline Total $(* *)$ & 107 & 41 & 12 & 19 & 176 & & 17.1 & 684.2 \\
\hline
\end{tabular}

* Species endemic to Rio de Janeiro state. ${ }^{*}$ Four individuals were seen but escaped in the course of the study: one unidentified frog, one $B$. didactylus and one $E$. brasiliensis during plot sampling, and one E. brasiliensis during transect sampling.

wet season (Tab. II). In Central America, litter frog densities are generally similar or higher than that of the present survey (Tab. II). In most studied areas of tropical Africa and Asia the estimated densities were lower than that of our study, except for one site at Iriomote Island (Ryuku Archipelago, Japan) for which a much higher value (41.8 ind $\left./ 100 \mathrm{~m}^{2}\right)$ was obtained (Tab. II). Our data thus reinforces the idea that higher densities of leaf litter frogs tend to occur in the Neotropical region compared to the Old World tropics.

Individuals of species with direct development numerically dominated the anuran assemblage at PEPT, as it has been observed in most studied Neotropical litter frog assemblages (e.g. Scott 1976, Lieberman 1986, Fauth et al. 1989, Giaretta et al 1997, 1999, Rосна et al. 2001, 2007). Euparkerella brasiliensis, a small direct-developing frog, was the most abundant frog species at the PETP and had the highest estimated value of mass per hectare of all frogs sampled in plots, despite its small body size. This is a poorly known species, probably due to its small body size and relatively limited geographical range (previously restricted to the municipalities of Rio de Janeiro and Guapimirim; IzECKSOHN 1988). Another small direct-developing frog, B. didactylus, the smallest frog sampled in the present study, was the second most abundant species in the study area. Brachycephalus didactylus (adult SVL up to $10-11 \mathrm{~mm}$ ) is arguably the world's smallest tetrapod species (Estrada \& Hedges 1996, Hedges et al. 2008) and it was previously known from only three other localities in the state of Rio de Janeiro (VAN SuUYs et al. 2007). The present data extend the distribution of E. brasiliensis and B. didactylus some $20 \mathrm{~km}$ to the east.

The estimated total mass of frogs per hectare was lower than that reported for another Atlantic forest area (Ilha Grande) by Rocha et al. (2001) based on data from 8 x $8 \mathrm{~m}$ plots $(1,150 \mathrm{~g} /$ 
Table II. Summary of data from studies of leaf litter frog assemblages using large-plot $(5 \times 5 \mathrm{~m}$ or larger) sampling in tropical rainforests worldwide. Acronyms for Brazilian states are: (AM) Amazonas, (RJ) Rio de Janeiro, and (SP) São Paulo.

\begin{tabular}{|c|c|c|c|c|}
\hline Locality & Altitude (m) & Season & Density (ind/100 m²) & Reference \\
\hline \multicolumn{5}{|l|}{ South America } \\
\hline Brazil, P. E. dos Três Picos (RJ) & $500-800$ & wet & 17.1 & This study \\
\hline Brazil, Reserva Ecológica de Guapiaçu (RJ) & $40-400$ & wet & 8.4 & Rocha et al. (2007) \\
\hline Brazil, Ilha Grande (RJ) & $220-230$ & wet & 5.9 & Rocha et al. (2001) \\
\hline Brazil, Morro São João (RJ) & $10-320$ & dry & 4.5 & Almeida-Gomes et al. (2008) \\
\hline Brazil, Serra do Japi (SP) & $850-1000$ & dry & 1.4 & GiARETTA et al. (1997) \\
\hline \multirow[t]{2}{*}{ Brazil, Parque Florestal de Itapetinga (SP) * } & $900-1250$ & wet & 5.1 & Giaretta et al. (1999) \\
\hline & & dry & 4.2 & \\
\hline \multirow[t]{2}{*}{ Brazil, INPA-WWF reserve (AM) } & 150 & wet & 6.0 & AlLMON (1991) \\
\hline & & dry & 3.0 & \\
\hline \multirow[t]{2}{*}{ Peru, Panguana } & 210 & wet & 15.5 & Tofт (1980a) \\
\hline & & dry & 4.4 & \\
\hline \multicolumn{5}{|l|}{ Central America } \\
\hline \multirow[t]{2}{*}{ Costa Rica, Osa } & lowland & wet & 18.9 & Scott (1976) \\
\hline & & dry & 14.0 & \\
\hline \multirow[t]{2}{*}{ Costa Rica, La Selva } & 100 & wet & 21.4 & \\
\hline & & dry & 13.4 & \\
\hline \multirow[t]{2}{*}{ Costa Rica, San Vito } & 1200 & wet & 62.3 & \\
\hline & & dry & 55.1 & \\
\hline Costa Rica, La Selva * & 60 & both & 15.7 & LIEBERMAN (1986) \\
\hline Costa Rica, La Selva * & lowland & dry & 11.5 & HEINEN (1992) \\
\hline \multirow[t]{2}{*}{ Panama, Pipeline road } & 30 & wet & 7.5 & ToFt (1980b) \\
\hline & & dry & 19.4 & \\
\hline \multirow[t]{2}{*}{ Panama, Carti road } & 300 & wet & 11.8 & \\
\hline & & dry & 30.9 & \\
\hline Panama, Silugandí & lowland & wet & 30.2 & Heatwole \& Sexton (1966) \\
\hline \multicolumn{5}{|l|}{ Asia } \\
\hline Thailand, Sakaerat ** & lowland & both & $0.5-2.6$ & INGER \& COLWELL (1977) \\
\hline Borneo, nanga Tekalit & lowland & both & 1.2 & LLoYD et al. (1968) \\
\hline Taiwan, Nanjen-shan Nature Reserve** & $10-460$ & both & $3.5-10.2$ & Huang \& Hou (2004) \\
\hline Japan, Iriomote Island & 25 & both & 41.8 & WatANABE et al. (2005) \\
\hline \multicolumn{5}{|l|}{ Africa } \\
\hline \multirow[t]{2}{*}{ Uganda, Kibale * } & 1530 & wet & 2.2 & VONESH (2001) \\
\hline & & dry & 1.5 & \\
\hline Cameroon, Douala-Edéa Game Reserve & lowland & dry & 9.4 & Scott (1982) \\
\hline
\end{tabular}

* Only density estimates from unburned/undisturbed sites were considered. ** Two different forest environments were sampled.

ha). As the estimated frog density was lower at Ilha Grande, this difference in mass may be due to the assemblage composition in each locality. At the PETP, the most abundant frogs found in plots were small (E. brasiliensis) to very small (B. didactylus), whereas at Ilha Grande the assemblage was dominated by species about equal in size (I. parva) or larger (Z. parvulus) than $E$. brasiliensis (RocHA et al. 2001). In another Atlantic rainforest area
(Giaretta et al. 1999), the estimated mass of frogs per hectare (476.6 g/ha) was slightly lower than that of the present study, whereas in rainforests studied in other parts of the world they were higher, being 1,088 g/ha in Peru (ToFT 1980a) and 11,460 $\mathrm{g} /$ ha in Iriomote island, Japan (WATANABE et al. 2005).

Although most species of frogs at the PETP were sampled in transects (75\% of all sampled species) and three species - 
Ischnocnema octavioi (Bokermann, 1965), Crossodactylus aeneus Müller, 1924 and Leptodactylus marmoratus Steindachner, 1867 - were recorded only by this method, three other species were sampled only using other methods. One species, $H$. binotatus, was sampled only in plots and the other two, P. appendiculata and Thoropa miliaris (Spix, 1824) (one individual each), were captured only by pitfall traps. Thus, the data indicates that, although a particular method may be more efficient to capture more individuals (plot sampling) or more species (transects), the three sampling methods should be used to better estimate the richness and abundance of frogs in leaf litter assemblages, at least in Atlantic Rainforest areas. Moreover, during the present study, frogs were captured mainly during the crepuscular and nocturnal transects (92.7\% of all individuals). This has also occurred in previous studies carried out in other Atlantic rainforest areas (Rocha et al. 2000, 2007, ALmEIDA-Gomes et al. 2008). Thus, the data obtained at the PETP reinforce the idea that most of the leaf litter frog activity in the Atlantic forest is crepuscular to nocturnal.

The PETP, created as recently as 2002, currently represents the largest protected area of Atlantic Rainforest in the state of Rio de Janeiro (Rocha et al. 2003). Although the present study represents a short-term survey carried out at a comparatively small area within this reserve, the results indicate a relatively high species richness and density of leaf litter frogs. This suggests that the whole area encompassed by the park (over 46,000 ha) may harbor a considerable anuran richness and numerous sites where the forest floor is densely populated by frogs. The presence of at least four species endemic to the state of Rio de Janeiro attest to the importance of the PETP as a conservation unit for anuran species, which are currently facing a worldwide decline due to factors such as global climate change, pollution, habitat loss, and the spread of diseases such as chytridiomycosis (e.g. Young et al. 2004, Toledo et al. 2006, NAvAS \& OTANI 2007).

\section{ACKNOWLEDGEMENTS}

This study was sponsored by Critical Ecosystem Partnership Fund, Conservação Internacional and Aliança para a Conservação da Mata Atlântica. CFDR (Processes 307653/20030 and 477715/2006-0) and MVS (Process 301401/2004-7) received research grants from the CNPq. CFDR received a research grant from Fundação de Amparo à Pesquisa do Estado do Rio de Janeiro (FAPERJ) through the "Programa Cientistas do Nosso Estado" (Process E-26/100.471.2007). Graduate fellowships were granted by the FAPERJ to CCS, by the CAPES to PAS, and by CNPq to VNTBJ. We are especially thankful to Alexander J. Davis for local support and for making many facilities available. We also thank CAG Cruz, J.P. Pombal Jr, C. Canedo, B.V.S. Pimenta, and E. Izecksohn for their help with the identification of frogs. Currently CCS is associated to the Programa de Pós-Graduação em Ecologia from Universidade Federal do Rio de Janeiro and receives a PhD grant from $\mathrm{CNPq}$.

\section{LITERATURE CITED}

Allmon, W.D. 1991. A plot study of forest floor litter frogs, Central Amazon, Brazil. Journal of Tropical Ecology 7 (4): 503-522.

Almeida-Gomes, M.; D. Vrcibradic; C.C. Siqueira; M.C. Kiefer; T. Klaion; P. Almeida-Santos, D. Nascimento, C.V. Ariani; V.N.T. Borges-Junior; R.F. Freitas-Filho, M. van Sluys \& C.F.D. Rocha. 2008. Herpetofauna of an Atlantic Rainforest area (Morro São João) in Rio de Janeiro State, Brazil. Anais da Academia Brasileira de Ciências 80 (2): 291-300.

CoRn, P.S. 1994. Straight-line drift fences and pitfall traps, p. 109-117. In: W.R. Heyer; M.A. Donnelly; R.W. McDiarmid; L.A.C. HAYEK \& M.S. Foster (Eds). Measuring and monitoring biological diversity: standard methods for amphibians. Washington DC, Smithsonian Institution Press, 364p.

Crump, M.L. \& N.J. Scott Jr. 1994. Visual encounter surveys, p. 84-92. In: W.R. Heyer; M.A. Donnelly; R.W. McDiarmid; L.A.C. HAYeK \& M.S. Foster (Eds). Measuring and monitoring biological diversity: standard methods for amphibians. Washington DC, Smithsonian Institution Press, 364p.

Duellman, W.E. 1999. Distribution patterns of amphibians in South America, p. 255-328. In: W.E. Duellman (Ed.). Patterns of distribution of amphibians: a global perspective. Baltimore, Johns Hopkins University Press, 633p.

Estrada, A.R.\& S.B. Hedges. 1996. At the lower size limit in tetrapods: a new diminutive frog from Cuba (Leptodactylidae: Eleutherodactylus). Copeia 1996 (4): 852-859.

FAUTH, J.E.; B.I. Crother \& J.B. SLOWINSKI. 1989. Elevational patterns of species richness, evenness and abundance of the Costa Rican leaf-litter herpetofauna. Biotropica 21 (2): 178-185.

Giaretta, A.A.; R.J. Sawaya; G. Machado; M.S. AraúJo; K.G. Facure; H.F. Medeiros \& R. Nunes. 1997. Diversity and abundance of litter frogs at altitudinal sites at Serra do Japi, Southeastern Brazil. Revista Brasileira de Zoologia 14 (2): 341-346.

Giaretta, A.A.; K.G. Facure; R.J. Sawaya; J.H.D. Meyer \& N. Chemin. 1999. Diversity and abundance of litter frogs in a montane forest of southeastern Brazil: seasonal and altitudinal changes. Biotropica 31 (4): 669-674.

Heatwole, H. \& O.J. Sexton. 1966. Herpetofaunal comparisons between two climatic zones in Panama. American Midland Naturalist 75 (1): 45-60.

Hedges, S.B.; W.E. Duellman \& M.P. Heinicke. 2008. New world direct-developing frogs (Anura: Terrarana): molecular phylogeny, classification, biogeography, and conservation. Zootaxa 1737: 1-182.

Heinen, J.T. 1992. Comparisons of the leaf litter herpetofauna in abandoned cacao plantations and primary rain forest in Costa Rica: some implications for faunal restoration. Biotropica 24 (3): 431-439.

Hofer, U. \& L.F. Bersier. 2001. Herpetofaunal diversity and abundance in tropical upland forests of Cameroon and Panama. Biotropica 33 (1): 142-152.

Huang, C.H. \& P.C.L. Hou. 2004. Density and diversity of litter Amphibians in a monsoon forest of southern Taiwan. 
Zoological Studies 43 (4): 795-802.

INGER, R.F. 1980. Relative abundances of frogs and lizards in forests of southeast Asia. Biotropica 12 (1): 14-22.

INGER, R.F. \& R.K. Colwell. 1977. Organization of contiguous communities of amphibians and reptiles in Thailand. Ecological Monographs 47 (3): 229-253.

IzECKSOHN, E. 1988. Algumas considerações sobre o gênero Euparkerella, com a descrição de três novas espécies (Amphibia, Anura, Leptodactylidae). Revista Brasileira de Biologia 48 (1): 59-74.

JAEger, R.G. \&, R.F. INGER. 1994. Quadrat sampling, p. 97-102. In: W.R. Heyer; M.A. Donnelly; R.W. McDiarmid; L.A.C. HaYeK $\&$ M.S. Foster (Eds). Measuring and monitoring biological diversity: standard methods for amphibians. Washington DC, Smithsonian Institution Press, 364p.

Lieberman, S.S. 1986. Ecology of the leaf litter herpetofauna of a Neotropical rainforest: La Selva, Costa Rica. Acta Zoologica Mexicana 15 (1): 1-71.

Lloyd, M.; R.F. Inger \& W. KING. 1968. On the diversity of reptile and amphibian species in a Bornean rainforest. American Naturalist 102 (928): 497-515.

Myers, N.; R.A. Mittermeier; C.G. Mittermeier \& G.A.B. Fonseca. 2000. Biodiversity hotspots for conservation priorities. Nature 403 (6772): 853-858.

Navas, C. \& L. Otani. 2007. Physiology, environmental change and anuran conservation. Phyllomedusa 6 (2): 83-103.

Rocha, C.F.D.; M. van Sluys; M.A.S. Alves; H.G. Bergallo \& D. VRcibradic. 2000. Activity of leaf-litter frogs: when should frogs be sampled? Journal of Herpetology 34 (2): 285-287.

Rocha, C.F.D.; M. van Sluys; M.A.S. Alves; H.G. Bergallo \& D. VRCibradic. 2001. Estimates of forest floor litter frog communities: a comparison of two methods. Austral Ecology 26 (1): 14-21.

Rocha, C.F.D.; H.G. Bergallo; M. van Sluys \& M.A.S. Alves. 2003. A biodiversidade nos grandes remanescentes florestais do estado do Rio de Janeiro e nas restingas da Mata Atlântica. São Paulo, Rima Editora, 160p.

Rocha, C.F.D.; H.G. Bergallo; J.P. Pombal Jr; L. Geise; M. Van Sluys; R. Fernandes \& U. Caramaschi. 2004. Fauna de anfíbios, répteis e mamíferos do estado do Rio de Janeiro, sudeste do Brasil. Publicações Avulsas do Museu Nacional 104: 3-23.

Rocha, C.F.D.; D. Vrcibradic D; M.C. Kiefer; M. Almeida-Gomes; V.N.T. Borges-Junior; P.C.F. Carneiro; R.V. Marra; P.A. Santos;
C.C. Siqueira; P. Goyannes-Araújo; C.G.A. Fernandes; E.C.N. Rubião \& M. van SLUYs. 2007. A survey of the leaf-litter frog community from an Atlantic forest area (Reserva Ecológica de Guapiaçu) in Rio de Janeiro State, Brazil, with an estimate of frog densities. Tropical Zoology 20 (1): 99-108.

Sсотт JR, N.J. 1976. The abundance and diversity of the herpetofauna of tropical forest litter. Biotropica 8 (1): 41-58.

ScotT JR, N.J. 1982. The herpetofauna of forest litter plots from Cameroon, Africa, p. 145-150. In: N.R. Scott JR (Ed.). Herpetological communities: a symposium of the Society for the Study of Amphibians and Reptiles and the Herpetologists' League. Washington DC, US Fish and Wildlife Service, 239p.

TAnizaki-Fonseca, K. \& T.P. Moulton. 2000. A fragmentação da Mata Atlântica no Estado do Rio de Janeiro e a perda de diversidade, p. 23-35. In: H.G. Bergallo; C.F.D. Rocha; M.A.S. Alves \& M. VAN SluYs (Eds). A fauna ameaçada de extinção do Estado do Rio de Janeiro. Rio de Janeiro, Eduerj, 166p.

ToFт, C. 1980a. Feeding ecology of thirteen syntopic species of anurans in a seasonal tropical environment. Oecologia 45 (1): 131-141.

Tofт, C. 1980b. Seasonal variation in populations of Panamanian litter frogs and their prey: a comparison of wetter and drier sites. Oecologia 47 (1): 34-38.

Toledo, L.F.; F.B. Brito; O.G.S. Araújo; L.O.M. Giasson \& C.F.B. HADDAD. 2006. The occurrence of Batrachochytrium dendrobatidis in Brazil and the inclusion of 17 new cases of infection. South American Journal of Herpetology 1 (3): 185-191.

van Sluys, M.; D. Vrcibradic; M.A.S. Alves; H.G. Bergallo \& C.F.D. Rосна. 2007. Ecological parameters of the leaf-litter frog community of an Atlantic Rainforest area at Ilha Grande, Rio de Janeiro state, Brazil. Austral Ecology 32 (3): 254260.

VONESH, J.R. 2001. Patterns of richness and abundance in a tropical African leaf-litter herpetofauna. Biotropica 33 (3): 502 510.

Watanabe, S.; N. NAKANishi \& M. IZAWA. 2005. Seasonal abundance in the floor-dwelling frog fauna on Iriomote Island of the Ryuku Archipelago, Japan. Journal of Tropical Ecology 21 (1): 85-91.

YounG, B.E.; S.N. Stuart; J.S. Chanson; N.A. Cox \& T.M. Boucher. 2004. Disappearing jewels: the status of New World amphibians. Arlington, Virginia, NatureServe, 54p.

Submitted: 23.VI.2008; Accepted: 11.III.2009.

Editorial responsibility: Glauco Machado 